\title{
AKUMULASI LOGAM BERAT PADA BATANG Eichhornia crassipes SOLMS PADA VARIASI MEDIA PENYARING SELAMA REMEDIASI AIR LINDI
}

\author{
Lian Anggraini ${ }^{1)}$ Marta Dinata ${ }^{2)}$ \\ Pendidikan Biologi FKIP Universitas Lancang Kuning \\ email $^{1)}$ :lianaggraini96@gmail.com \\ email $^{2)}$ :martadinata@unilak.ac.id
}

\begin{abstract}
ABSTRAK: Air lindi dapat berdampak negatif terhadap lingkungan disekitar TPA karena air lindi mengandung bahan pencemar yang dapat mengganggu kesehatan manusia, mencemari lingkungan dan biota perairan. Air lindi mengandung senyawa kimia organik maupun anorganik serta sejumlah bakteri phatogen. Penelitian ini bertujuan untuk mengetahui akumulasi logam berat pada batang eceng gondok pada variasi media penyaring selama remediasi air lindi. Penelitian ini dilaksanakan di lingkungan kampus FKIP UNILAK dan laboratorium LL DIKTI wilayah X Padang, Sumatera Barat.Metode penelitian yang digunakan adalah metode True eksperimen dengan Rancangan Acak Lengkap yang terdiri dari 4 perlakuan dengan 5 ulangan. Parameter yang diamati adalah suhu, bau, $\mathrm{pH}$. Data dianalisis menggunakan uji Analisis of Varians One -Way dengan taraf signifikan $(\alpha)=0,01$ dan uji lanjut dengan Duncan's Multiple Range Test pada taraf signifikan $(\alpha)=0.01$. Hasil penelitian selama 30 hari menunjukkan bahwa terdapat pengaruh signifikan media penyaring dengan tumbuhan eceng gondok dalam penurunan logam berat yang efektif terdapat pada perlakuan P3( Podzolik merah kuning, ferolit, tumbuhan eceng gondok, air lindi) dan P1(Podzolik merah kuning, tumbuhan eceng gondok, air lindi) dengan nilai efektivitas P3 logam berat Cr pada batang 0,1214\%, P1 logam berat Fe pada batang $0,0944 \%$.
\end{abstract}

\section{Kata kunci : Logam berat, batang eceng gondok (Eichhornia crassipes SOLMS), media penyaring, fitoreremediasi, dan air lindi.}

ABSTRACT: Leachate water can have a negative impact on the environment around the landfill because leachate contains pollutants that can disrupt human health, pollute the environment and aquatic biota. Leachate contains organic and inorganic chemical compounds as well as a number of phatogenous bacteria. This study aims to determine the accumulation of heavy metals in water hyacinth stems on various filter media during leachate remediation. This research was carried out in the FKIP UNILAK campus and LL DIKTI laboratory in X Padang, West Sumatra. The research method used was the True Experiment method with Completely Randomized Design consisting of 4 treatments with 5 replications. The parameters observed were temperature, odor, pH. Data were analyzed using Analysis of Variance One -Way test with a significant level $(\alpha)=0.01$ and further test with Duncan's Multiple Range Test at a significant level $(\alpha)=0.01$. The results of the 30-day study showed that there was a significant effect of filter media on water hyacinth plants in the reduction 
of effective heavy metals found in P3 treatment (red yellow podzolic, ferolite, water hyacinth plants, leachate) and P1 (red yellow podzolic, water hyacinth plant, leachate water) with the effectiveness of metal P3 Cr weight on the stem $0.1214 \%, P 1$ heavy metal Fe on the rod $0.0944 \%$.

Keywords: Heavy metals, water hyacinth stems (Eichhornia crassipes SOLMS), filter media, phytoreremediation, and leachate water.

\section{PENDAHULUAN}

\section{A. LATAR BELAKANG}

Persoalan sampah juga dapat mengancam kota Pekanbaru sebagai salah satu kota besar di Sumatera yang jumlah penduduknya terus meningkat sehingga kebutuhan penduduknya juga ikut meningkat. Berkaitan dengan itu, pemerintah kota Pekanbaru telah melakukan berbagai upaya penanggulangan sampah mulai dari kegiatan penyuluhan dan penyadaran masyarakat tentang kebersihan, penjemputan sampai dari rumah-rumah penduduk untuk diangkut ke Tempat Pembuangan Akhir (TPA) sampah (Sari \& Sari, 2014).

Keberadaan tempat pembuangan akhir sampah (TPAS) memiliki fungsi yang sangat penting, yaitu sebagai pengolahan akhir sampah baik yang akan didaur ulang sebagai kompos ataupun hanya ditimbun setelah disortir oleh pemulung. Jumlah sampah di TPAS yang sangat besar akan menyebabkan proses dekomposisi alamiah berlangsung secara besar-besaran pula. Proses dekomposisi tersebut akan mengubah sampah menjadi pupuk organik dan menimbulkan hasil samping yaitu leachate (air lindi) (Darnoto \& Astuti, 2009).

Tempat Pembuangan Akhir (TPA) di Pekanbaru berada di wilayah Muara Fajar, Kecamatan Rumbai. Berdasarkan observasi dan wawancara dengan petugas TPA Muara Fajar pada awal pembukaan lahan TPA Muara Fajar menerapkan sistem penimbunan sampah dengan tanah, dibuat seperti barisan yang berlapis secara teratur 
(controlled landfil) dalam pengolahan sampah. Hal ini ditandai dengan adanya saluran air di bawah tanah (drainase) untuk mengendalikan air hujan, saluran pengumpul lindi (leachate), kolam penampung, fasilitas pengendalian gas metan dan lain-lain, tetapi peningkatan jumlah sampah yang melebihi kapasitas lahan penampungan sampah menjadikan TPA menerapkan sistem terbuka (open dumping) dalam pengolahan sampah.

Air lindi dapat berdampak negatif terhadap lingkungan disekitar TPA karena air lindi mengandung bahan pencemar yang dapat mengganggu kesehatan manusia, mencemari lingkungan dan biota perairan. Air lindi mengandung senyawa kimia organik maupun anorganik serta sejumlah bakteri phatogen. Selain itu juga mengandung amoniak, timbal, $\mathrm{pH}$ yang konsentrasinya sangat tinggi sehingga menyebabkan terganggunya kehidupan makhluk hidup disekitar TPA. Air lindi juga mengandung mikroba parasit seperti kutu air (Sarcoptes sp) yang menyebabkan gatal-gatal pada kulit
(Susanto et al, 2004). Berdasarkan masalah tersebut maka perlu adanya pengolahan air lindi yang bertujuan untuk mengurangi dan mencegah dampak negatifnya pada lingkungan. Salah satu hal yang dapat dilakukan untuk mengurangi kadar pencemar air lindi tersebut yaitu dengan fitoremediasi.

Fitoremediasi (phytoremediation) merupakan suatu sistem dimana tanaman tertentu yang bekerja sama dengan mikroorganisme dalam media (tanah, koral dan air). Perpaduan ini dapat mengubah zat kontaminan (pencemar/polutan) menjadi kurang atau tidak berbahaya bagi lingkungan. Proses yang dilakukan tumbuhan untuk menguraikan zat kontaminan yang mempunyai rantai molekul kompleksmenjadi bahan yang tidak berbahaya dengan susunan molekul yang lebih sederhana yang dapat berguna bagi pertumbuhan tumbuhan itu sendiri (Anam et al, 2011).

Tumbuhan air yang digunakan dalam fitoremediasi ini yaitu eceng gondok (Eichhornia crassipes solms). Hal ini karena eceng gondok banyak 
terdapat di sekitar Rumbai dan eceng gondok juga mampu secara efektif mengurangi bahan pencemar pada limbah pabrik kelapa sawit seperti TSS, TDS, kekeruhan, sulfat dan klorida (Syafrani, 2007).

Logam berat dibagi menjadi dua jenis yaitu, (1) logam berat esensial yang merupakan logam dalam jumlah tertentu yang sangat dibutuhkan oleh organisme. Akan tetapi, logam tersebut bisa menimbulkan efek racun jika dalam jumlah yang berlebihan, contohnya Fe. (2) Logam berat tidak esensial adalah logam yang keberadaannya dalam tubuh masih belum diketahui manfaatnya, bahkan bersifat racun, contohnya yaituCr. Menurut Soehardi, F., \& Dinata, M. (2018) Logam berat yang mencemari lingkungan, baik dalam udara, air, dan tanah berasal dari proses alami dan kegiatan industri. Proses alami dapat berasal dari bebatuan gunung berapi yang memberikan kontribusi ke lingkungan udara, air, dan tanah. Kegiatan manusia yang dapat menambah pencemaran lingkungan berupa kegiatan industri, pertambangan, pembakaran bahan bakar, serta kegiatan domestik lain yang mampu meningkatkan kandungan logam di lingkungan udara, air, dan tanah (Widowati dalam Lisa, 2013).

\section{METODE PENELITIAN}

Penelitian ini adalah eksperimen murni (True Exsperiment), dengan desain Rancangan Acak Lengkap (RAL) yang terdiri dari 4 perlakuan dan 5 kali pengulangan (Hanafiah, 2011).

Penelitian ini dilaksanakan pada bulan April- Mei 2019 di lingkungan kampus FKIP Universitas Lancang Kuning Pekanbaru dan laboratorium LLDIKTI wilayah X Padang, Sumatera Barat. Instrumen Penelitian:

\section{a. Alat}

Alat yang digunakan dalam penelitian ini adalah bak penampung(ember), thermometer, $\mathrm{pH}$ meter, oven, timbangan, neraca analitik,aluminium foil.

\section{b. Bahan}

Bahan yang digunakan dalam penelitian ini adalah PMK, zeolit, ferrolit, air lindi, dan tumbuhan eceng gondok (Eichhornia crassipes solms). 
Parameter yang diamati dalam penelitian ini adalah Parameter logam berat jenis kronium $(\mathrm{Cr})$ dan iron $(\mathrm{Fe})$, di ukur menggunakan alat AAS (Atomic Absorbsion Spektrophotometri).

\section{HASIL DAN PEMBAHASAN}

\section{A. Hasil Penelitian}

Berdasarkan penelitian yang telah dilaksanakan di lingkungan kampus Fakultas Keguruan dan Ilmu Pendidikan Universitas Lancang Kuning dan laboratorium LL DIKTI wilayah $\mathrm{X}$ padang, sumatera barat yang dimulai pada tanggal 29 April 2019 dan berakhir pada tanggal $28 \mathrm{Mei}$ 2019, maka diperoleh hasil sebagai berikut :
a). Konsentrasi Logam $\mathrm{Cr}$ pada Batang

Berdasarkan pengamatan media penyaring terhadap konsentrasi logam berat $\mathrm{Cr}$ pada batang dalam setiap perlakuan selama tiga puluh hari yang menggunakan Rancangan Acak lengkap (RAL), maka didapat rekapitulasi data seperti tabel dibawah ini:

Tabel: 1 Rekapitulasi Konsentrasi Logam Cr Pada Batang

\begin{tabular}{|c|c|c|c|c|c|}
\hline \multirow{2}{*}{ No } & Perlakuan & \multicolumn{3}{|c|}{ Rerata konsentrasi logam Cr pada batang eceng } \\
& & & Hondok (mg/L) \\
\cline { 3 - 6 } & & Hari 0 & Hari 10 & Hari 20 & Hari 30 \\
\hline 1 & P1 & 2,5442 & 2,6084 & 2,717 & 2,792 \\
\hline 2 & P2 & 2,5448 & 2,596 & 2,6258 & 2,7038 \\
\hline 3 & P3 & 2,5474 & 2,575 & 2,6166 & 2,8618 \\
\hline
\end{tabular}

b). Konsentrasi Logam Fe Pada Batang

Berdasarkan pengamatan

media penyaring terhadap konsentrasi logam berat $\mathrm{Fe}$ pada batang dalam setiap perlakuan selama tiga puluh hari yang menggunakan Rancangan Acak Lengkap (RAL), maka didapat rekapitulasi data seperti tabel dibawah ini: 
Tabel 2 Rekapitulasi Konsentrasi Logam Fe Pada Batang

\begin{tabular}{|c|c|c|c|c|c|}
\hline \multirow{2}{*}{ No } & Perlakuan & \multicolumn{3}{|c|}{ Rerata konsentrasi Fe pada batang eceng gondok } \\
& & & Hari 10 & Hari 20 & Hari 30 \\
\cline { 3 - 6 } & & Hari 0 & Ho & 2,6866 \\
\hline 1 & P1 & 2,4538 & 2,517 & 2,607 & 2,596 \\
\hline 2 & P2 & 2,4544 & 2,4976 & 2,4178 & 2,5146 \\
\hline B 3 & P3 & 2,4542 & 2,4376 & 2,4866 & terendah terdapat pada P2 dengan \\
\hline b
\end{tabular}

berdasarkan hasil parameter fisika dan kimia selama remediasi rerata suhu berkisar $27^{\circ} \mathrm{C}-29,4^{\circ} \mathrm{C}$ nilai $\mathrm{pH}$ mencirikan basa yang berkisar 8,71 9,66 bau pada hari ke 30 sudah mulai berkurang dibandingkan dengan baku mutu suhu $\pm 3, \mathrm{pH} 5$, bau tidak berbau, logam Fe(besi) 1, logam Cr(cromium) 0,05 sehingga hasil yang didapat lebih besar dari standar baku mutu air PERMENKES 2017.

Dari hasil penelitian diketahui logam berat pada $\mathrm{Cr}$ (Kromium) pada batang yang paling tertinggi terdapat pada P3 dengan menggunakan media $(\mathrm{PMK}+$ ferolit + Tanaman eceng gondok + Air lindi) dengan nilai efektivitas $0,1214 \%$, dan $\mathrm{Cr}$ (kromium) pada batang yang paling menggunakan media (PMK + zeolit + tanaman eceng gondok + air lindi) dengan nilai efektivitas $0,062 \%$. Logam berat pada $\mathrm{Cr}$ (Kromium) air lindi yang paling sedikit terdapat pada P3 (PMK + feroli +, Tanaman eceng gondok + Air lindi) karena logam berat lebih banyak terakumulasi pada batang eceng gondok, dan logam berat $\mathrm{Cr}$ (kromium) pada air lindi yang paling tertinggi terdapat pada P2 dengan menggunakan media (PMK + zeolit + tanaman eceng gondok + air lindi) karena logam berat lebih sedikit terakumulasi pada batang. Dengan rerata suhu berkisar $27^{\circ} \mathrm{C}-29,4^{0} \mathrm{C}$, sementara rerata pada $\mathrm{pH}$ berkisar 8,71 - 9,66, yang menunjukkan bahwa $\mathrm{pH}$ termasuk golongan basa, dan bau air 
lindi yang sudah mulai berkurang terdapat pada hari ke 30 karena sudah tidak berbau.

Dari hasil penelitian diketahui logam berat pada $\mathrm{Fe}$ (besi) pada batang yang paling tinggi terdapat pada P1 (PMK + Tanaman eceng gondok + air lindi) dengan nilai efektivitas 0,0944\%, dan Fe (besi) pada batang yang paling terendah terdapat pada $\mathrm{P} 3$ $(\mathrm{PMK}+$ ferolit + tanaman eceng gondok + air lindi) dengan nilai efektivitas $0,0062 \%$. Logam berat $\mathrm{Fe}$ (besi) pada air lindi yang paling sedikit terdapat pada P1 (PMK + Tanaman eceng gondok + Air lindi) karena logam berat lebih banyak terakumulasi pada batang eceng gondok, dan logam berat $\mathrm{Fe}$ (besi) pada air lindi yang paling tertinggi terdapat pada P3 $(\mathrm{PMK}+$ ferolit + tanaman eceng gondok + air lindi) karena logam berat lebih sedikit terakumulasi pada batang. Dengan rerata suhu berkisar $27^{\circ} \mathrm{C}$ $29,4^{\circ} \mathrm{C}$, sementara rerata pada $\mathrm{pH}$ berkisar $8,71 \quad-\quad 9,66$ yang menunjukkan bahwa $\mathrm{pH}$ termasuk golongan basa, dan bau air lindi yang sudah mulai berkurang terdapat pada hari ke 30 karena sudah tidak berbau.

Hal ini sejalan dengan penelitian Lestari et al (2007) yang berjudul "Efektivitas Eceng Gondok (Eichhornia Crassipes solms) Dalam Penyerapan Kadmium (Cd) Pada Leachate Tpa Gunung Tugel" menunjukan bahwa Luas penutupan eceng gondok $75 \%$ optimal menurunkan Cd sebesar 29,279\%. Waktu tinggal 6 hari optimal dalam menurunkan kadar $\mathrm{Cd}$ sebesar $27,211 \%$. 2. Kombinasi luas penutupan $75 \%$ dengan lama waktu tinggal 6 hari optimal dalam menurunkan $\mathrm{Cd}$ adalah $39,770 \%$.

\section{KESIMPULAN DAN SARAN}

\section{A. Kesimpulan}

Berdasarkan hasil penelitian
yang dilakukan selama 30 hari
menggunakan media penyaring PMK,
Zeolit, Ferolit, Air lindi dan tanaman
eceng gondok.penelitian ini dilakukan
di lingkungan kampus FKIP
Universitas Lancang Kuning dan
laboratorium LL DIKTI wilayah X
Padang, Sumatera Barat. Yang mana


penelitian menggunakan True experimen dengan Rancangan Acak Lengkap yang mempunyai 4 perlakuan dan 5 kali pengulangan. Parameter yang dilihat pada penelitian ini yaitu penyerapan kadar logam Fe (besi) dan $\mathrm{Cr}$ (kromium) menggunakan tanaman eceng gondok.

Dapat disimpulkan bahwa terdapat pengaruh yang signifikan dengan jenis media penyaring dan tumbuhan eceng gondok terhadap logam berat $\mathrm{Fe}$ dan Cr.yang mana logam berat pada Fe yaitu 0,0944 $\mathrm{mg} / \mathrm{L}$ dan $\mathrm{Cr}$ yaitu 0,1214 mg/L. Terutama yang menggunakan media penyaring Zeolit dan Ferolit mampu menyerap logam berat dengan baik karena media zeolit dan ferolit tersebut memiliki daya serap untuk menyerap logam berat tersebut dan dapat mempengaruhi parameter $\mathrm{pH}$, pada air lindi dan tidak mempengaruhi parameter suhu.

\section{B. Saran}

Berdasarkan penelitian yang telah dilaksanakan jika menggunakan tanaman eceng gondok pada penelitian ini, maka sebaiknya pilihlah tanaman eceng gondok yang segar dan lebih tua agar tanaman tersebut dapat bertahan hidup dalam air lindi tersebut, dan jika memilih media penyaring PMK sebaiknya pilihlah yang agak berpasir agar pada perlakuan P1 dapat lebih mudah keluar airnya.

\section{DAFTAR PUSTAKA}

Ali, M. (2011). Monograf Rembesan Air Lindi (Leachate) Dampak Pada Tanaman Pangan dan Kesehatan. Upn Press : Surabaya.

Anam, M., M., Evi, K. \& Bambang, S. (2011). Penurunan Kandungan Logam $\mathrm{Pb}$ dan $\mathrm{Cr}$ Leachate Melalui Fitoremediasi Bambu Air (Equisetum hyemale) dan Zeolit. Jurnal Keteknikan Pertanian Tropis dan Biosistem. Vol. 1, No. 2.

Anggraini, S., L. (2013). Zeolit dan Manfaatnya. Tersedia : http://sucililaanggraini.files .wordpress.com/2013/04/n ebeng-yo-do.pdf $\quad[18$ September 2014]. 
Darnoto, S. \& Astuti, D. (2009). Pengaruh Penambahan Poly Aluminium Chloride (PAC) Terhadap Tingkat Kekeruhan, Warna, dan TotalSuspended Solid (TSS) Pada Leachate (Air Lindi) di TPAS Putri Cempo Mojosongo

Surakarta. Jurnal

Kesehatan. Vol. 2, No. 2.

Effendi, H. 2003. Telaah Kualitas Air Bagi Pengelolaan Sumber Daya dan Lingkungan Perairan. Cetakan Kelima. Kanisius : Yogyakarta.

Emelda, L., Putri, S., M. \& Simparmin Br. G. (2013). Pemanfaatan Zeolit Alam Teraktivasi untuk Adsorpsi Logam Krom (Cr3+). Jurnal Rekayasa Kimia dan Lingkungan. Vol. 9, No. 4.

Esmiralda, \& Oktarina, D. (2012). Pengaruh COD, Fe, dan $\mathrm{NH}_{3}$ dalam Air Lindi LPA Air Dingin Kota Padang
Terhadap Nilai LC50.

Jurnal Teknik Lingkungan UNAND. Vol. 9, No. 1.

Soehardi, F., \& Dinata, M. (2018). Recent Analysis of Maximum Rain Period. International Journal of Engineering \& Technology, 7(2.3), 63-67. doi:http://dx.doi.org/10.14 419/ijet.v7i2.3.12323

Hardyanti, N. \& Huboyo, H., S., (2009). Evaluasi Instalasi Pengolahan Lindi Tempat Pembuangan Akhir Putri Cempo Kota Surakarta. Jurnal Presipitasi. Vol. 6, No. 1.

Hardyanti, N. \& Fitri, N. D. (2006). Studi Evaluasi Instalasi Pengolahan Air Bersih Untuk Kebutuhan Domestik dan Non Domestik (Studi Kasus Perusahaan Tekstil Bawen Kabupaten Semarang). Jurnal Presipitasi. Vol.1, No.1.

Harjoso, T Dan A. S. D. Purwanto. (2002). Pemanfaatan Tanah 
Podzolik Merah Kuning

Melalui Pemberian Pupuk

Kandang dan EM4 Bagi

Program Pengembangan

Babi Corn. Jurnal

Pengembangan Desa. 2 (2)

27-73
Mutu Air Kesehatan Lingkungan Dan

Persyaratan Kesehatan Air Untuk Keperluan Higiene Sanitasi, Kolam Renang, Solus Per Aqua Dan Pemandian Umum

Prahutama, A. (2013). Estimasi Kandungan Do (Dissolved Oxygen) di Kali Surabaya dengan Metode Kriging. Statistika. Vol. 1, No. 2. Instalasi Koagulasi dan Kolam Fakultatif Untuk Pengolahan Air Lindi (Studi Kasus TPA Bakung Bandar Lampung). Jurnal Rekayasa. Vol. 13, No. 1.

Nonong. (2010). Pemanfaatan Limbah

Tahu Sebagai Bahan Penyerap Logam Krom, Kadmium dan Besi Dalam Air Lindi TPA, Jurnal Pembelajaran Sains Vol 6, No 2, 257-269

Permenkes No. 32 Tahun 2017 tentang, Standar Baku
Priyanti \& Yunita, E. (2013). Uji Kemampuan Daya Serap Tumbuhan Genjer (Limnocharis Flava) Terhadap Logam Berat Besi ( $\mathrm{Fe})$ dan Mangan $(M n)$. Prosiding Semirata FMIPA Universitas Lampung : Lampung.

Putra, I., M., I., M. \& Purnomo, A. (2012). Studi Penggunaan Ferrolte Sebagai Campuran Media Filter 
Untuk Penurunan Besi (Fe) dan Mangan (Mn) Pada Air Sumur. Artikel. Jurusan Teknik Lingkungan : Surabaya.

Resti, Afdal., 2017. Karakteristik Lindi dari Tempat Pembuangan Sampah di Akhir (TPA) Air Dingin, Kota Padang, sumatera barat. Jurnal SNFA. ISSN 2548-8325.

Sari, E., \& Sari, M. (2014). Analisis Kualitas Air Lindi Tempat Pembuanagan Akhir (TPA) Muara Fajar dan Pengaruhnya Terhadap Air Tanah. Laporan Penelitian, Fakultas Keguruan dan Ilmu Pendidikan Universitas Lancang Kuning. Pekanbaru. Tidak Diterbitkan.

Susanto, J., P., Sri, P., G., Sri, M. \& Siti, H., I. (2004). Pengolahan Lindi (Leachate) dari TPA
Dengan Sistem KoagulasiBiofilter Anaerobic. Jurnal Teknologi LingkunganP3TL-BPPT. Vol.5, No. 3.

Syafrani. (2007). Kajian Pemanfaatan Media Penyaring dan Tumbuhan Air Setempat Untuk Pengendalian Limbah Cair Pada SubDAS Tapung Kiri, Propinsi Riau. Disertasi, Sekolah Pasca Sarjana, Institut Pertanian Bogor : Bogor. Tidak Diterbitkan.

Santoso. B. (2006). Pemberdayaan Lahan Podsolik Merah Kuning dengan Tanaman Rosela (Hibiscus sabdariffa L.) di Kalimantan Selatan. Perspektif. Vol. 5, No. 1. .

Suhendrayatna. (2007). Teknologi Pengolahan Limbah, Bahan Beracun Berbahaya (B3), Perpustakaan 
Nasional, Syiah Kuala,
Banda Aceh.

Suhendrayatna. (2013). Merkuri:

Bahaya, Sumber

Pencemar, Dan

Pengelolaan di

Lingkungan. Kampanye

dan sosialisasi Dampak

Merkuri Terhadap

Lingkungan. Meulaboh, 9

Desember 2013.

Upit R.P, Asrul S.S., Nuning, V.H.

(2011). Kemampuan

Tumbuhan Air Sebagai

Agen Fitoremediator

Logam Berat Kromium

(Cr) yang Terdapat pada

Limbah Cair Industri

Batik, Berkala Perikanan

Terburuk, ISSN 0126-4265

Vol. 39, No.1 Februari

2011.

Widowati, Sastiono, R., Jusuf. (2008).

Efek Toksik Logam. Andi

Offset, Yogyakarta.

Bio-Lectura: Jurnal Pendidikan Biologi, Vol 7, No 1, April 2020 